\title{
Antioxidant and in vivo hepatoprotective effects of Gardenia gummifera L.f. fruit methanol extract
}

\author{
N. M. Vinaykumar, Riaz Mahmood*, V. Krishna, B. Ravishankara and Sudhesh L. Shastri
}

\begin{abstract}
Background: Gardenia gummifera L.f. (Family: Rubeacea) is used in indigenous system of medicine to cure many diseases. To authenticate the traditional medicinal claim investigation has been under taken to evaluate the antioxidant and hepatoprotective activities of Gardenia gummifera L.f. fruit methanol extract (GFME).
\end{abstract}

Method: GFME was evaluated using various antioxidant assays, including DPPH and Nitric oxide radical scavenging assays. The protective effects of GFME were studied in carbon tetrachloride reduced biochemical markers of hepatic injury such as serum glutamyl oxaloacetate transaminase (SGOT), serum glutamyl pyruvate transaminase (SGPT), alkaline phosphatase (ALP), total protein (TP), total bilirubin (TB) and direct bilirubin (DB) and in silico studies were carried out to screen the GFME phytocompounds.

Results: The extract showed significant antioxidant activity in DPPH and Nitric oxide radical scavenging with $I_{50}$ value of 131.11 and 175.95 respectively. Quantitative phytochemical assay determines the presence of alkaloids $69.1 \mu \mathrm{g} / 1 \mathrm{mg}$ and phenolics $76.5 \mu \mathrm{g} / 1 \mathrm{mg}$. GC-MS analysis of aromatic extract resulted in 36 compounds. Among them, compounds 2, 3-Dihydro-3,5-dihydroxy-6-methyl-4 h-pyran-4-one, 2-furancarboxaldehyde 5-(hydroxymethyl) and Quinic acid are the major ones. The fruit methanol extract showed significant in vivo hepatoprotective activity by altering the levels of liver function biochemical parameters such as SGOT, SGPT, ALP, TP, TB and DB. Histology of the liver section also confirms the hepatoprotective activity of GFME. Molecular docking of GC-MS profiled phytocompounds with the target protein TGF- $\beta 1$ and PPARa also confirmed the therapeutic effect with good hydrogen bonding and hydrophobic interactions.

Conclusion: Thus the present study clearly strengthened the traditional medicinal claim of the plant Gardenia gummifera L.f. possessing the hepatoprotective drug.

Keywords: Gardenia gummifera L.f., Antioxidants, Hepatoprotective activity, Biochemical markers

\section{Background}

The liver is the largest organ in the body playing a vital role in the regulation of various physiological processes. Its activity is related to diverse fundamental functions, such as detoxification, secretion, storage and metabolism [1]. It has ability to detoxify exogenous (toxic compounds) and endogenous (waste metabolites) substances of

\footnotetext{
*Correspondence: riaz_sultan@yahoo.com

Department of Biotechnology, Kuvempu University, Shankaraghatta, Shimoga, Karnataka, India
}

\section{Springer Open}

organisms. The liver is also involved in the biochemical processes of providing nutrients and supplying energy. In addition, it aids in the metabolism of fats and carbohydrates, storage of vitamins and secretion of bile [2, 3].

Currently, hepatic diseases become principal threats to public health among worldwide population. Nearly 20, 000 deaths occur each year due to liver illnesses [4]. Hepatic disease is a term that indicates damage to the liver cells, tissues and liver function. The imbalance in the level of antioxidants and pro-oxidants leads to oxidative stress causing potential damage to the organ [5]. 
This damage can be induced by various biological factors (bacteria, virus, and parasites) and autoimmune diseases (immune hepatitis, primary biliary cirrhosis), as well as by the action of different chemical, drugs [high doses of paracetamol and anti tuberculosis drugs], toxic compounds [carbon tetrachloride $\left(\mathrm{CCl}_{4}\right)$ ] and excessive consumption of alcohol [6]. Despite enormous advances in modern medicine, there is no effective drug that stimulate hepatic function. Additionally, some drugs can make adverse effects on body. Thus, it is necessary to identify alternative pharmaceuticals for the treatment of hepatic diseases that are more effective and less toxic [7].

Herbal therapies are in extreme demand in developed and developing countries for primary healthcare [8]. Since ancient times, natural products have been the strength of traditional systems in the supervision of human ailments throughout the globe and also been an integral part of history and culture [9]. It is well established that natural products played precious roles in modern drug development [10]. Even though acceptance of the synthetic merchandises increased due to its making cost, time efficacy, easy quality control, stringent regulation and quick effects, but their safety and efficacy always remained questionable, resulting in the inclination towards the natural products by more than $80 \%$ of the total population in the developing world, because of their time tested safety and efficacy [11]. Presently, great attention is being focused on the practice of natural antioxidants to safeguard the human body mainly brain tissues from the oxidative injury affected by free radicals. Synthetic drugs in use have shown harmful side effects compared to natural compounds, therefore, there is a need for additional active, cost-effective and less toxic antioxidants drawn from natural sources [12].

Gardenia gummifera L.f. is a deciduous tree belongs to the Rubiaceae family. It is commonly known as gummy gardenia. It is distributed in the forests of Tamil Nadu, Andhra Pradesh, Kerala and Karnataka, This plant is well known for its application in folk medicine. In the indigenous system of medicine Ayurveda, it is called Nadihingu (Sanskrit), Dikamali (Hindi), Kadbikke (Kannada), Sirukkambil (Tamil), Kambimaram (Malayalam), Chitta mali (Telugu) $[13,14]$.

This plant is claimed to have numerous medicinal properties possessing astringent and carminative properties that are used in the management of dyspepsia and hemorrhoid. It is also useful in the treatment of flatulence for cleaning foul ulcers and wounds, anticonvulsants $[15,16]$, Sitosterol, D-mannitol, Oleanoic aldehyde, 19 hydroxyerythrodiol and erythrodiol have been reported from the plant [17]. The preliminary phytochemical investigation of Gardenia gummifera L.f. has shown that it is very rich in phytoconstituents. In view of this study the present study was designed to systematically screen the phytocompounds and carryout the GC-MS analysis. The prophylactic effect of the aromatic compounds of the fruit methanol extract was evaluated along with antioxidant and in vivo hepatoprotective effects. The molecular docking of GC-MS analyzed compounds from fruit methanol extract against the therapeutic target proteins was also performed to authenticate the therapeutic effects of Gardenia gummifera L.f.

\section{Materials and methods \\ Plant material}

The fruits of Gardenia gummifera L.f. were collected in August 2018 (during the rainy season) from Sakarayapatna, Chikmagalur District, Karnataka, India. The plant has been identified and authenticated by an inhouse taxonomist Dr. V. Krishna, Professor, Post Graduate Studies and Research in Biotechnology, Kuvempu University, and the voucher specimen is maintained at Kuvempu University herbaria (KUBPHS80).

\section{Preparation of extract}

Plant material was washed with distilled water and dried at room temperature to constant weights. The dried fruit materials were blended separately to powder and subjected to successive solvent extraction from nonpolar to polar solvents like petroleum ether, chloroform and methanol respectively. The extracts were prepared using the soxhlet apparatus. The extract were filtered, pooled and concentrated to dryness under reduced pressure in a rotary evaporator (Buchi, Flawil, Switzerland). In sequential extraction, methanol extract found to give more yield.

\section{Preliminary phytochemical analysis Qualitative analysis}

The qualitative estimation of the Gardenia gummifera L.f. extract was carried out as stated by Lotfy et al. [18].

\section{Quantitative analysis}

Determination of Total Phenolics The total phenolic contents of the extract were quantified by the spectrophotometric method of Singleton. $20 \mu \mathrm{l}$ of extract $(5 \mathrm{mg} /$ ml) was mixed with $0.25 \mathrm{ml}$ of Folin-Ciocalteau reagent and $0.75 \mathrm{ml}$ of $20 \%$ sodium carbonate solution. The reaction mixture was allowed to stand in the light for 3 min and incubated for $2 \mathrm{~h}$ in dark. The absorbance was measured at $765 \mathrm{~nm}$ using UV-Visible Spectrophotometer. Total phenolics were measured by calibration curve achieved from measuring the absorbance of known concentration of Gallic acid standard $(0-100 \mu \mathrm{g} / \mathrm{ml})$. The concentrations were expressed as $\mu \mathrm{g}$ of Gallic acid equivalents per $\mathrm{ml}$ and all the estimations were executed in triplicates [19]. 
Determination of total alkaloids The quantitative determination of alkaloids was according to the methodology by Harborne. A total of $40 \mathrm{ml}$ of acetic acid (10\%) added to $1 \mathrm{~g}$ of extract and allowed to stand for $4 \mathrm{~h}$. The filtrate was then concentrated on a water bath to get $1 /$ 4th of its original volume. Concentrated ammonium hydroxide was added drop wise to the extracted sample until the precipitation was complete. The complete solution was permitted to settle and the collected precipitate was washed with dilute ammonium hydroxide and then filtered. The residue was dried in an oven and the percentage of the alkaloid is expressed mathematically [20].

Percentage of total alkaloids $(\%)=$ Weight of residuex 100/Weight of a sample taken.

\section{GCMS analysis}

The fruit methanol extract of Gardenia gummifera L.f. was subjected to GC-MS analysis with Shimadzu instrument by GC-MS solutions software and compounds were separated using Rtx-5, capillary column $(30 \mathrm{~m} \times$ $0.25 \mathrm{~mm}$, film thickness $0.25 \mu \mathrm{m})$. The Split ratio $1: 25$, the injector temperature maintained at $300^{\circ} \mathrm{C}$. The column temperature was programmed at $60^{\circ} \mathrm{C}$, followed by $300^{\circ} \mathrm{C}$ at $10 \mathrm{~min}$. About $1 \mu \mathrm{l}$ sample was injected into the column by the split mode. Helium gas $(99.999 \%)$ was used as a carrier gas at a constant flow rate of $1 \mathrm{ml} / \mathrm{min}$ and the Mass scanning range was $40-500 \mathrm{~m} / \mathrm{z}$. The identification of compounds was based on Willey and NIST libraries as well as the comparison of their retention indices. The compounds were acknowledged after comparison with those available in the computer library (NIST and Willey) attached to the GC-MS instrument and the results obtained have been tabulated [21].

\section{In-vitro antioxidant activity}

Determination of DPPH radical scavenging activity 2, 2-diphenylpicrylhydrazyl (DPPH) radical scavenging activity of GFME was conducted by adding $1 \mathrm{ml}$ of an extract with different concentrations in different test tubes followed by addition of $3 \mathrm{ml}$ of $0.004 \% \mathrm{DPPH}$ in $95 \%$ ethanol into all tubes and the mixture was left in the dark for $30 \mathrm{~min}$ before its absorbance was read at 517 $\mathrm{nm}$. The absorbance of the reaction mixture was measured at $517 \mathrm{~nm}$. Ascorbic acid was taken as a reference standard. DPPH radical scavenging activity was calculated using the following formula; Percentage of inhibition $=[(\mathrm{A}$ control $-\mathrm{A}$ test $) / \mathrm{A}$ control $] \times 100$, where $\mathrm{A}$ control is the absorbance of the control reaction and $\mathrm{A}$ test is the absorbance of the extract reaction. The $\mathrm{IC}_{50}$ value was calculated using the formula $\mathrm{IC}_{50}=[(\Sigma \mathrm{C} / \Sigma \mathrm{I}) \times$ $50]$, where $\Sigma C$ is the sum of extracts concentrations used to test and $\Sigma \mathrm{I}$ is the sum of the percentage of inhibition at different concentrations [22].
Determination of nitric oxide radical scavenging activity Nitric oxide radical scavenging activity of GFME was conducted by adding $250 \mu \mathrm{l}$ extracts of different concentrations $(100,200,300 \mu \mathrm{g})$ by adding into different test tubes along with sodium nitroprusside $(5 \mathrm{mM}$, in phosphate buffer saline, $\mathrm{pH}$ 7.4). The combination was incubated at room temperature under light source (24 W compact fluorescent light bulb). Later $150 \mathrm{~min}$, $0.6 \mathrm{~mL}$ of the mixture was transferred into a new tube containing $0.6 \mathrm{~mL}$ of Griess reagent (1\% sulphanilamide and $0.1 \% \mathrm{~N}$-(1-naphthyl)-ethylenediamine dihydrochloride in $5 \%$ phosphoric acid). After incubating for $10 \mathrm{~min}$ in darkness, absorbance was recorded at $546 \mathrm{~nm}$. Ascorbic acid was used as a standard. Percentage of inhibition was calculated using formula; \% Inhibition $=[$ (A control - A test)/A control] $\times 100$, where A control is the absorbance of the control reaction and $\mathrm{A}$ test is the absorbance of the extract reaction. The $\mathrm{IC}_{50}$ value was calculated using the formula $\mathrm{IC}_{50}=[(\Sigma \mathrm{C} / \Sigma \mathrm{I}) \times 50]$, where $\Sigma \mathrm{C}$ is the sum of extracts concentrations used to test and $\Sigma \mathrm{I}$ is the sum of the percentage of inhibition at different concentrations [23].

\section{Animals and management}

Adult male albino rats of Wistar strain, weighing about $160-220 \mathrm{~g}$ were used for the acute toxicity studies. Before the experiment, the animals were acclimatized for 14 days to laboratory conditions. The rats were maintained at room temperature, with a $12 \mathrm{~h}$ light/dark cycle. During the period of acclimatization, animals were housed in polycarbonate cages with a pellet diet and water. All processes in this study were executed according to the CPCSEA guidelines. The experimental protocol was permitted by the Institutes Animal Ethics Committee (NCP/IAEC/CL/213/01/2012-13) [24].

\section{Acute toxicity study}

The acute toxicity test of GFME was performed according to the Organization of Economic Cooperation and Development (OECD) guidelines 423 [25]. In this study, overnight fasted rats were administered orally with extracts prepared in mili Q-water, while the mili-Q water administered to control groups as a vehicle orally. The fixed-dose method OECD guidelines 423 specified by CPCSEA was implemented for toxicity studies. After the administration of Gardenia gummifera L.f. extracts animals were observed individually to investigate for toxic effect changes if any for the first $4 \mathrm{~h}$ and once daily for 14 days [26].

\section{In vivo hepatoprotective activity}

The albino rats weighing between 160 and $220 \mathrm{~g}$ of either sex were used in this evaluation. Animals were divided into five groups of each containing six animals. 
Olive oil was used as vehicle control for suspending the standard drugs and the extracts. Group I (vehicle control) animals received only olive oil orally ( $1 \mathrm{ml} / \mathrm{kg}$ body weight). Group II (negative control) animals were administered with $0.5 \mathrm{ml} / \mathrm{kg}$ of $\mathrm{CCl}_{4}$ (1:1 ratio, $\mathrm{CCl}_{4}$ : Olive oil). Group III (standard control) received the standard ascorbic acid at a dose of $100 \mathrm{mg} / \mathrm{kg}$ b.w for 7 days. Group IV and V (test groups) received the test sample GFME at a dose of 200 and $400 \mathrm{mg} / \mathrm{kg}$ b.w respectively. The test extract and vehicle control were administered orally for 7 days at different dosages. On the 7 th day after $6 \mathrm{~h}$ of the administration, animals of all groups were sacrificed by cervical dislocation and the sample of blood was collected, allowed to clot at room temperature for $30 \mathrm{~min}$. The blood samples was centrifuged and the clear serum was separated at $4000 \mathrm{rpm}$ for $30 \mathrm{~min}$ and serum samples was stored at $-40{ }^{\circ} \mathrm{C}$ until use for the assessment of different biochemical parameters like serum glutamyl oxaloacetate transaminase (SGOT), serum glutamyl pyruvate transaminase (SGPT), alkaline phosphatase (ALP), total protein (TP), total bilirubin (TB) and direct bilirubin (DB) $[27,28]$. Hepatic liver tissue was sensibly removed, washed and homogenized in KCL $(1.15 \%)$ and phosphate buffer $(10 \mathrm{mM})$ with EDTA (Ph7.4) and centrifuged at 10,000 rpm for $10 \mathrm{~min}$. The supernatant of the homogenate was used for enzyme assays. Leftover hepatic samples were kept for different histological studies [29].

\section{Histological studies}

The liver tissue was excised instantly after sacrifice. The tissue was washed with normal saline and dried out by blotting paper fixed by formalin (10\%). The fixed liver was dehydrated in gradual ethanol grades (30-100\%) and embedded in paraffin. Five micrometers microtome section were prepared and stained using alum hematoxylin and eosin dye then examined under the microscope for the evaluation of histological changes [30].

\section{In silico analysis}

\section{ADME and toxicity properties analysis}

The ADMET can be defined by the following phases: absorption, distribution, metabolism, excretion, and toxicity. Lipinski "Rule of five" is commonly used as a filter for drug-like properties [31]. The inputs for analysis of 2, 3Dihydro-3, 5-dihydroxy-6-methyl-4 h-pyran-4-one (Compound I), 2-furancarboxaldehyde 5-(hydroxymethyl)(Compound II) and Quinic acid (Compound III) were obtained from the ChemSpider database. They were used as an input for in silico analysis. The physicochemical properties of the compound were calculated using an online Molinspiration cheminformatics server. ADME and Toxic properties of the compounds were calculated using an online PreADMET web-based program [32, 33].

\section{Molecular docking studies}

The structure of the target Peroxisome proliferatoractivated receptor alpha (PPAR $\alpha)$ and Transforming growth factor-beta 1 (TGF- $\beta 1$ ), was obtained from Protein Data Bank (PDB ID; 5HYK, and 1VJY). Structures of phytoconstituents 2, 3-Dihydro-3, 5-dihydroxy-6-methyl-4 h-pyran-4-one (Compound I), 2-furancarboxaldehyde 5(hydroxymethyl)-(Compound II) and Quinic acid (Compound III) were drawn and analyzed using ChemDraw Ultra 12.0. 3D coordinates were obtained by using PRODRG online server [34]. Active pockets for proteins were obtained from the CASTp server [35]. Intermediary steps, such as energy minimization, protein and ligands preparation, and grid box creation were completed using the Graphical User Interface program AutoDock Tools (ADT). AutoDock saved the prepared file in PDBQT format. AutoDock/Vina was employed for docking with protein and ligand data along with grid box properties in the configuration file. AutoDock/Vina employs iterated local search global optimizer [36]. During the docking procedure, both the protein and ligands were considered as rigid. After the successful completion of the docking runs, different conformations of the ligands known as Binding modes were obtained with their respective binding affinity and the stable one which happens to be with the lowest binding affinity was picked and aligned with receptor structure for further analysis [37].

\section{Statistical analysis}

The results were statistically analyzed using one-way ANOVA using a software ezANOVA followed by one way ANOVA with Dunnett's multiple comparison tests were employed. The difference in values at $P \leq 0.02$ was considered as statistically significant.

\section{Results}

\section{Qualitative and quantitative analysis}

In sequential extraction methanol extract provided more yield with significant amount of secondary phytocompounds which is proved by qualitative and quantitative phytochemical estimation. Qualitative analysis of GFME revealed the presence of alkaloids, phenolic compounds, terpenoids, and saponins. The quantitative investigation revealed that the presence of phenolics and alkaloid compounds at the concentrations of $76.5 \mu \mathrm{g} / 1 \mathrm{mg}$ and $69.1 \mu \mathrm{g} / 1 \mathrm{mg}$ respectively.

\section{GC-MS analysis}

The chemical compositions of the GFME were investigated using GC-MS. The mass spectra of the compounds found in the GFME were matched by National Institute of Standards and Technology (NIST) library (Fig. 1). 


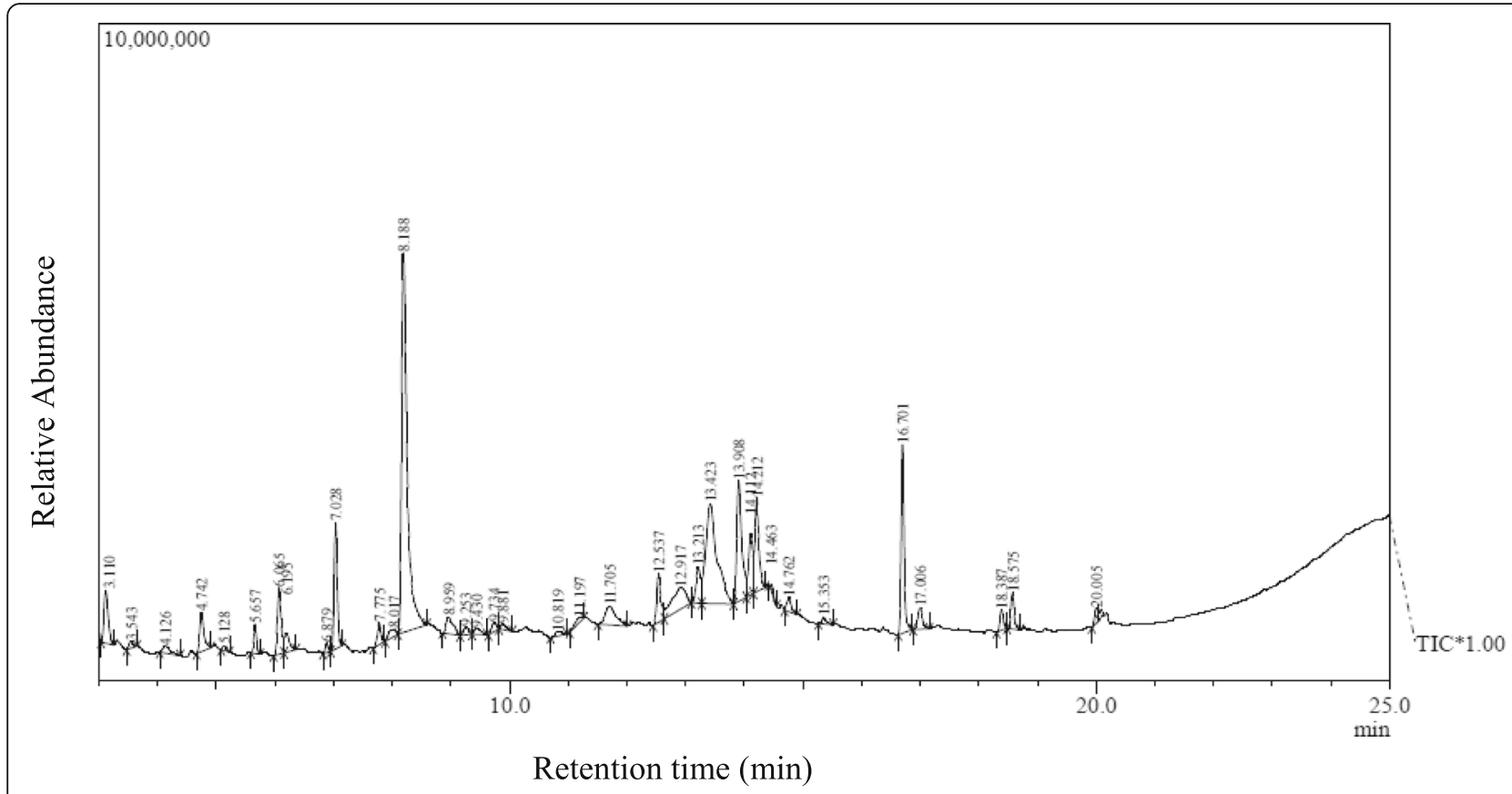

Fig. 1 GC-MS chromatogram of Gardenia gummifera L.f. fruit methanol extract

The GC-MS analysis showed the presence of 36 phytocompounds in the sample (Table 1). Among them, 2Furancarboxaldehyde, 5-(hydroxymethyl) - $\left(\mathrm{C}_{6} \mathrm{H}_{6} \mathrm{O}_{3}\right)$ exhibited the highest peak area of $25.94 \%$ and the retention time of $8.188 \mathrm{~min}$. Followed by the Quinic acid $\left(\mathrm{C}_{7} \mathrm{H}_{12} \mathrm{O}_{6}\right)$ with an area of $13.60 \%$ and retention time of $13.423 \mathrm{~min}$. These are the major phytocompounds present in the GFME.

\section{In vitro antioxidant assay}

Plants with antioxidant capacity are useful for medicinal applications. Therefore, in the present study, the antioxidant capacity of Gardenia gummifera L.f. extract has been carried out. The free radical scavenging ability of GFME against DPPH and Nitric oxide radicals is shown in Table 2. The GFME showed DPPH radical scavenging activity in a dose-dependent manner in a range of $69.17 \pm 0.21$ to $82.29 \pm 0.56 \%$. The $\mathrm{IC}_{50}$ values for extract and standard (ascorbic acid) are 131.11 and $114.93 \mu \mathrm{g} /$ $\mathrm{ml}$, respectively. In Nitric oxide radical scavenging activity dose-dependent range is $45.10 \pm 0.96$ to $54.78 \pm 0.21 \%$ and the $\mathrm{IC}_{50}$ values of extract and standard (ascorbic acid) are 175.95 and $144.45 \mu \mathrm{g} / \mathrm{ml}$, respectively.

\section{Acute toxicity studies}

Acute toxicity studies were undertaken according to a fixed-dose method as per the OECD 423 test guidelines. An effort was also made to detect $\mathrm{LD}_{50}$ of GFME. Physical observations showed no signs of behavioural pattern and there was no mortality and weight loss observed at the concentration of $2000 \mathrm{mg} / \mathrm{kg}$ b.w. It is supposed that $2000 \mathrm{mg} / \mathrm{kg}$ is the cut off dose. As per the toxicology guidelines, $1 / 10$ th and $1 / 5$ th of the dosage i.e. $(200 \mathrm{mg} /$ $\mathrm{kg})$ and $(400 \mathrm{mg} / \mathrm{kg})$ were taken as effective doses for all further experiments with rat models.

\section{In vivo hepatoprotective activity}

\section{Assessment of liver function by the level of biochemical markers}

The present study has been attempted to evaluate the role of hepatoprotective activity of fruit methanol extract of plant Gardenia gummifera L.f.

The study showed a significant increase $(p<0.0001)$ in serum SGOT $(137.38 \pm 1.30)$ and SGPT $(217.15 \pm 1.45)$ levels on $\mathrm{CCl}_{4}$ toxicity (Fig. 2). After the treatment with GFME, the toxicity levels of SGOT $(123.36 \pm 2.37$ in 200 $\mathrm{mg} / \mathrm{kg}$ and $116.71 \pm 2.14$ in $400 \mathrm{mg} / \mathrm{kg}$ ) and SGPT $(155.17 \pm 2.73$ in $200 \mathrm{mg} / \mathrm{kg}$ and $142.36 \pm 1.57$ in 400 $\mathrm{mg} / \mathrm{kg}$ ), decreased when compared to the control groups. In ALP determination there is a significant increase in the level of enzyme observed $(p<0.0001)$ in $\mathrm{CCl}_{4}$ toxicity $(187.91 \pm 1.53)$ as depicted in Fig. 2 . However, after the treatment with the GFME samples, the increased ALP level was controlled (159.12 \pm 1.45 and $145.16 \pm 1.79$ in $200 \mathrm{mg} / \mathrm{kg}$ and $400 \mathrm{mg} / \mathrm{kg}$ respectively) when compared to control groups. In the estimation of total bilirubin and direct bilirubin there is significant increase $(p<0.02)$ in $\mathrm{CCl}_{4}$ toxicity $(2.16 \pm 0.5$ and $1.74 \pm$ 0.04) (Fig. 3), but later treatment with GFME sample, the total bilirubin $(1.77 \pm 0.12$ in $200 \mathrm{mg} / \mathrm{kg}$ and $1.44 \pm$ 
Table 1 Chemical composition of Gardenia gummifera L.f. fruit extract

\begin{tabular}{|c|c|c|c|}
\hline SL. No & R Time (min) & Area \% & Compound \\
\hline 1. & 3.110 & 2.58 & Furfural \\
\hline 2. & 3.543 & 0.33 & Butanoic acid, 2-ethyl-3-oxo-, methyl ester \\
\hline 3. & 4.126 & 0.61 & 1,2-Cyclopentanedione \\
\hline 4. & 4.742 & 1.97 & Dihydroxy-2,5-dimethyl-3(2H)-furan-3-one \\
\hline 5. & 5.128 & 0.22 & Maltol \\
\hline 6. & 5.657 & 1.04 & Pentanoic acid, 4-oxo- \\
\hline 7. & 6.065 & 3.16 & 1,3,5-Triazine-2,4,6-triamine \\
\hline 8. & 6.195 & 1.08 & Furyl hydroxymethyl ketone \\
\hline 9. & 6.879 & 0.36 & 2-Propanamine, N-methyl-N-nitroso- \\
\hline 10. & 7.028 & 4.89 & 2,3-dihydro-3,5-dihydroxy-6-methyl-4 h-pyran-4-one \\
\hline 11. & 7.775 & 1.02 & Thiophene, 2,3-dihydro- \\
\hline 12. & 8.017 & 0.65 & 3-Methoxy-hexane-1,6-diol \\
\hline 13. & 8.188 & 25.94 & 2-Furancarboxaldehyde, 5-(hydroxymethyl)- \\
\hline 14. & 8.959 & 1.44 & 4H-Pyran-4-one, 2,3-dihydro-3,5-dihydroxy-6-methyl- \\
\hline 15. & 9.253 & 0.47 & Cyclohexane, 1,4-diethoxy-, trans- \\
\hline 16. & 9.430 & 0.49 & 1-Carbmethoxy-3,3-dimethyldiaziridine \\
\hline 17. & 9.734 & 0.52 & Pentanoic acid, propyl ester \\
\hline 18. & 9.881 & 0.37 & 2-Ethyl-3-methoxycyclopropanecarboxylic acid, methyl ester \\
\hline 19. & 10.819 & 0.38 & 2-Propenoic acid, 3-phenyl- \\
\hline 20. & 11.197 & 0.44 & 1,2:5,6-Dianhydrogalactitol \\
\hline 21. & 11.705 & 2.42 & D-Allose \\
\hline 22. & 12.537 & 2.57 & Benzoic acid, 4-hydroxy-3-methoxy \\
\hline 23. & 12.917 & 3.86 & .beta.-D-Lyxofuranoside, 5-O-(.beta.-D-lyxofuranosyl)-decyl- \\
\hline 24. & 13.213 & 2.18 & Azelaic Acid \\
\hline 25. & 13.423 & 13.60 & $(1 \mathrm{R}, 3 \mathrm{R}, 4 \mathrm{R}, 5 \mathrm{R})-(-)-\mathrm{Quinic}$ acid \\
\hline 26. & 13.908 & 7.17 & Hydrazinecarboxamide, 2-(2-methylcyclohexylidene)- \\
\hline 27. & 14.112 & 3.10 & Acetate, [4-hydroxy-4-(1-methylethyl)-5-methyl-2-hexynyl] ester \\
\hline 28. & 14.212 & 4.81 & Pyrimidine-2,4(1H,3H)-dione, 6-hydroxy-5-methyliminomethyl \\
\hline 29. & 14.463 & 0.25 & 2-Propanone, 1-hydroxy-3-(4-hydroxy-3-methoxyphenyl)- \\
\hline 30. & 14.762 & 0.72 & Acetate, [4-hydroxy-4-(1-methylethyl)-5-methyl-2-hexynyl] ester \\
\hline 31. & 15.353 & 0.37 & 3-Hydroxy-4,5-dimethoxybenzoic acid \\
\hline 32. & 16.701 & 6.91 & I-(+)-Ascorbic acid 2,6-dihexadecanoate \\
\hline 33. & 17.006 & 1.16 & Hexadecanoic acid, ethyl ester \\
\hline 34. & 18.387 & 0.86 & Oleic Acid \\
\hline 35. & 18.575 & 1.39 & Octadecanoic acid \\
\hline 36. & 20.005 & 0.69 & 14,15,16-Trinor-8.xi.-labdan-6.beta.-ol, 8,13-epoxy- \\
\hline
\end{tabular}

$0.05400 \mathrm{mg} / \mathrm{kg})$ and direct bilirubin $(0.86 \pm 0.05$ in 200 $\mathrm{mg} / \mathrm{kg}$ and $0.66 \pm 0.03$ in $400 \mathrm{mg} / \mathrm{kg}$ ) levels decreased when compared to the control groups. Similarly, in total protein estimation there is a significant decrease $(p<$ $0.0001)$ in $\mathrm{CCl}_{4}$ toxicity $(2.47 \pm 0.12)$ as shown in Fig. 3, but after the treatment with GFME sample, the total protein $(4.58 \pm 0.11$ and $5.52 \pm 0.13$ in $200 \mathrm{mg} / \mathrm{kg}$ and $400 \mathrm{mg} / \mathrm{kg}$ respectively) level increased when compared to control groups.

\section{Histological studies}

In the histological studies of the liver tissue, the section of normal control animal showed normal hepatic cells with a well-preserved cytoplasm, prominent nucleus and central vein. The $\mathrm{CCl}_{4}$ treated hepatic liver tissue cells showed a total loss of normal hepatic architecture with cell necrosis and evident vacuolation of hepatocytes. Pre-treatment with GFME at the dose of 200 and 400 $\mathrm{mg} / \mathrm{kg}$ b.w exhibited protective capacity and regaining of 
Table 2 In vitro antioxidant assay of GFME

\begin{tabular}{|c|c|c|c|c|c|}
\hline SL. No & Activity & Extract concentration $(\mu \mathrm{g} / \mathrm{ml})$ & $\%$ of activity & $\mid C_{50} \mu \mathrm{g} / \mathrm{ml}$ & Standard $I C_{50}$ in $\mu \mathrm{g} / \mathrm{ml}$ \\
\hline \multirow[t]{3}{*}{1} & \multirow[t]{3}{*}{ DPPH radical scavenging assay } & 100 & $69.17 \pm 0.21$ & \multirow[t]{3}{*}{131.11} & \multirow[t]{3}{*}{114.93} \\
\hline & & 200 & $77.35 \pm 0.39$ & & \\
\hline & & 300 & $82.29 \pm 0.56$ & & \\
\hline \multirow[t]{3}{*}{2} & \multirow[t]{3}{*}{ Nitric oxide radical scavenging assay } & 100 & $49.08 \pm 0.87$ & \multirow[t]{3}{*}{175.95} & \multirow[t]{3}{*}{144.45} \\
\hline & & 200 & $54.78 \pm 0.21$ & & \\
\hline & & 300 & $66.64 \pm 0.39$ & & \\
\hline
\end{tabular}

The results shown are averages of three independent experiments, values are Mean \pm SEM

normal histological appearance (Fig. 4). The administration of GFME at a dose of $400 \mathrm{mg} / \mathrm{kg}$ b.w offered protection more effectively when compared to the lower dose of $200 \mathrm{mg} / \mathrm{kg}$ b.w. Silymarin exhibited a potential hepatoprotective effect with the appearance of normal histological features and reduced the degenerative changes in the liver tissue. Thus, the results clearly indicate the hepatoprotective potential of GFME against $\mathrm{CCl}_{4}$ induced liver damage in experimental rats.

\section{In silico analysis}

\section{Physicochemical properties of phytocompounds}

The prediction of physicochemical properties such as, octanol-water partition coefficient (milogP), Molecular polar surface area (TPSA), molecular weight (MW), number of rotatable bonds (norbt) and number of $\mathrm{OH}$ atoms (nOHNH) affect absorption and bioavailability of drug molecule. According to Lipinskis Rule of Five, there were no violations in the compound I (2,3-Dihydro-3,5-dihydroxy-6-methyl-4h-pyran-4-one), compound II (2-furancarboxaldehyde 5-(hydroxymethyl)-) and compound III (Quinic acid) identified by GC-MS analysis of GFME
(MW $>500$ and $\mathrm{NH}$ or $\mathrm{OH}>5$ ). The TPSA value and number of rotatable bonds indicated good bioavailability. The TPSA values for the above compounds are $66.76 \AA$, $50.44 \AA$, and $118.21 \AA$ and the number of rotatable bonds found to be 0,2 , and 1 respectively. Rotatable polar atomic bonds increased the flexibility of molecules for more adaptable and efficient interaction with the enzyme active site and the values of TPSA of compound I (2,3-Dihydro3,5-dihydroxy-6-methyl-4h-pyran-4-one), compound II (2-furancarboxaldehyde 5-(hydroxymethyl)-) and compound III (Quinic acid) indicated the good oral bioavailability. The data are presented in Table 3 .

\section{ADME and toxic properties}

The HIA (human intestinal absorption) values for the compound I (2,3-Dihydro-3,5-dihydroxy-6-methyl-4 hpyran-4-one), compound II (2-furancarboxaldehyde 5(hydroxymethyl)-) and compound III (Quinic acid) are $75.91 \%, 89.88 \%$, and $20.28 \%$ respectively. The data of ADME and toxic properties of the compounds are shown in Table 4. These data indicate that among the tested compounds, compound II (2-furancarboxaldehyde

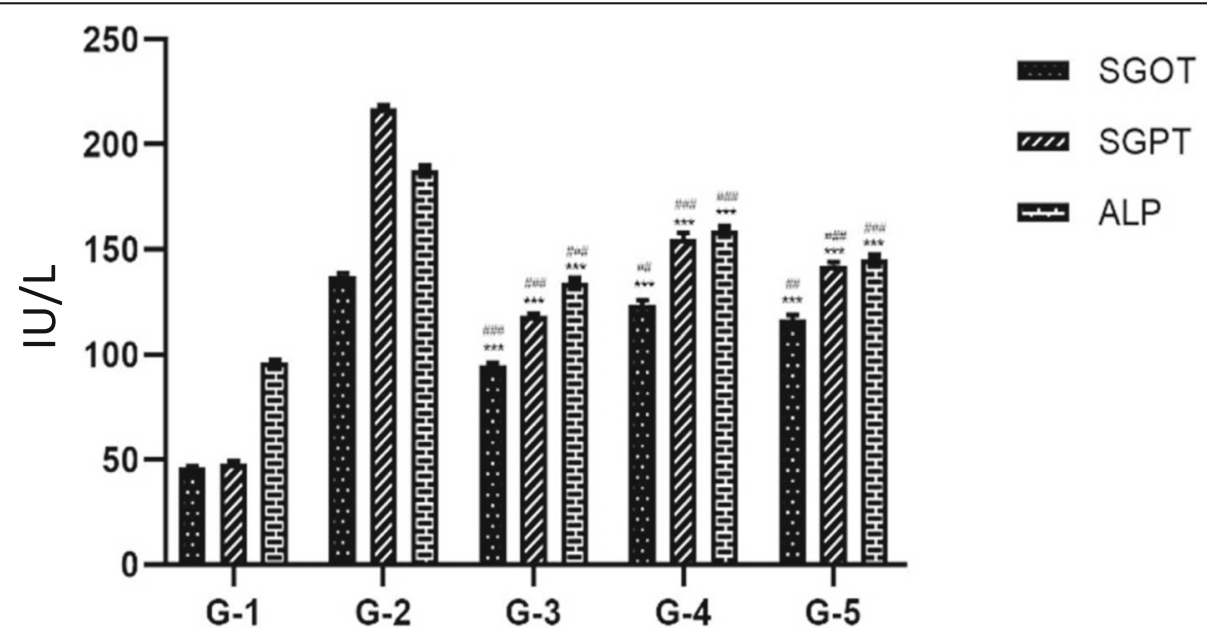

Fig. 2 Effect of GFME on enzyme SGOT, SGPT, ALP levels in blood serum of $\mathrm{CCl}_{4}$ induced hepatotoxicity. Values are mean \pm S.E.M. symbol represent statistical significance; *\#p<0.02, **\#\#p 0.001 and ***\#\#p<0.0001.* indicates the comparison of G- 1 with G-3, G-4, G-5; \# indicates the comparison of G- 2 with G-3, G- 4, G-5.SGOT- Serum glutamyl oxaloacetate transaminase, SGPT- Serum glutamyl pyruvate transaminase, ALP-Alkaline phosphatase. G1- normal control, G2-negative control, G3- standard, G4- GFME (200mg), G5- GFME (400mg) 


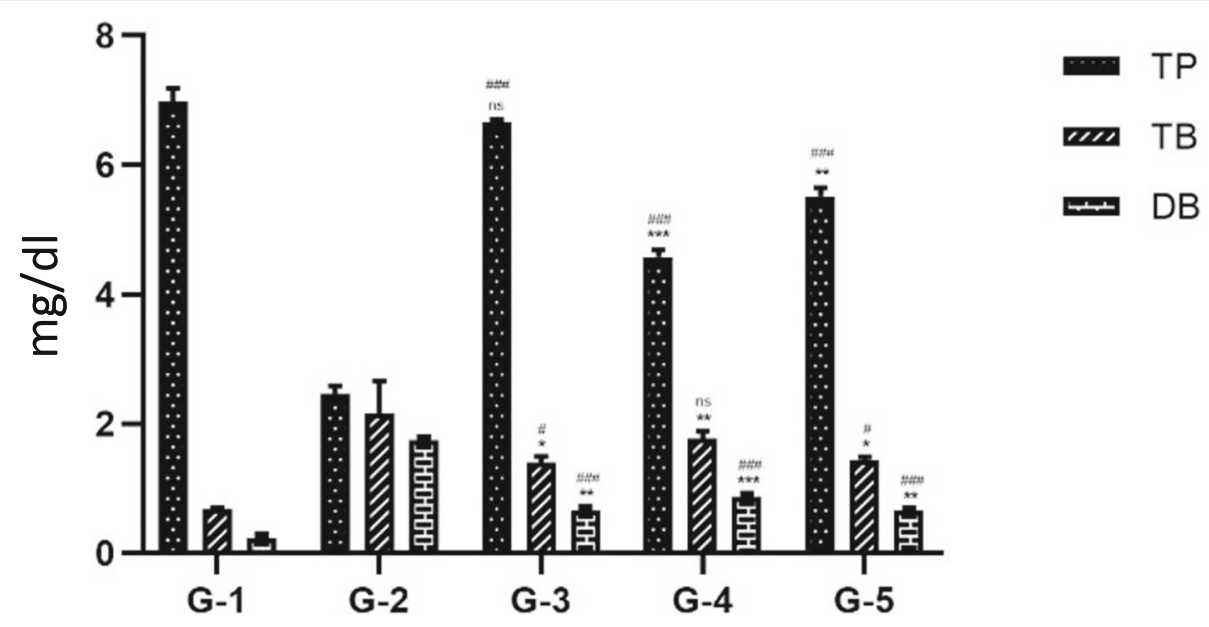

Fig. 3 Effect of GFME on enzyme TP, TB, and DB levels in blood serum of $\mathrm{CCl}_{4}$ induced hepatotoxicity. Values are mean \pm S.E.M. symbol represent statistical significance; *\#p<0.02, **\#\#p<0.001 and **\#\#\#p<0.0001.* indicates the comparison of G- 1 with G-3, G- 4, G-5; \# indicates the comparison of G- 2 with G-3, G- 4, G-5. TP- Total protein, TB- Total bilirubin, DB- Direct bilirubin. G1- normal control, G2-negative control, G3- standard, G4- GFME (200mg), G5- GFME (400mg)

5-(hydroxymethyl)-) can be well absorbed via the intestinal tract. In addition, compound III (Quinic acid) showed good permeability to Cacok2 cell (8.27242) and to MDCK cell model (0.530). In the distribution phase, the PPB binding assessment of compound I exhibited strong binding energy with plasma proteins (predicted value of $38.437 \%$ ). In addition, BBB penetration revealed that the compound showed low absorption in CNS (predicted value $0.273,0.511$ and $0.428 \%$ ). The skin permeability is another important risk assessment factor of the compounds during accidental contact with the skin and the compounds had revealed the least skin permeability
$(-4.75733,-2.61671$ and -4.96717$)$. In the toxicity phase, the carcinogenic effects of the compound were evaluated.

\section{Molecular docking}

The docking results have proven that, the ligand molecules of compound I (2,3-Dihydro-3,5-dihydroxy-6-methyl-4 h-pyran-4-one), compound II (2-furancarboxaldehyde 5-(hydroxymethyl)-) and compound III (Quinic acid) showed the binding affinity of $-4.0,-4.6$ and -4.3 respectively. There is 1 to 2 hydrogen bonding and good hydrophobic interactions against the amino acid molecules of TGF- $\beta 1$ protein (Fig. 5).

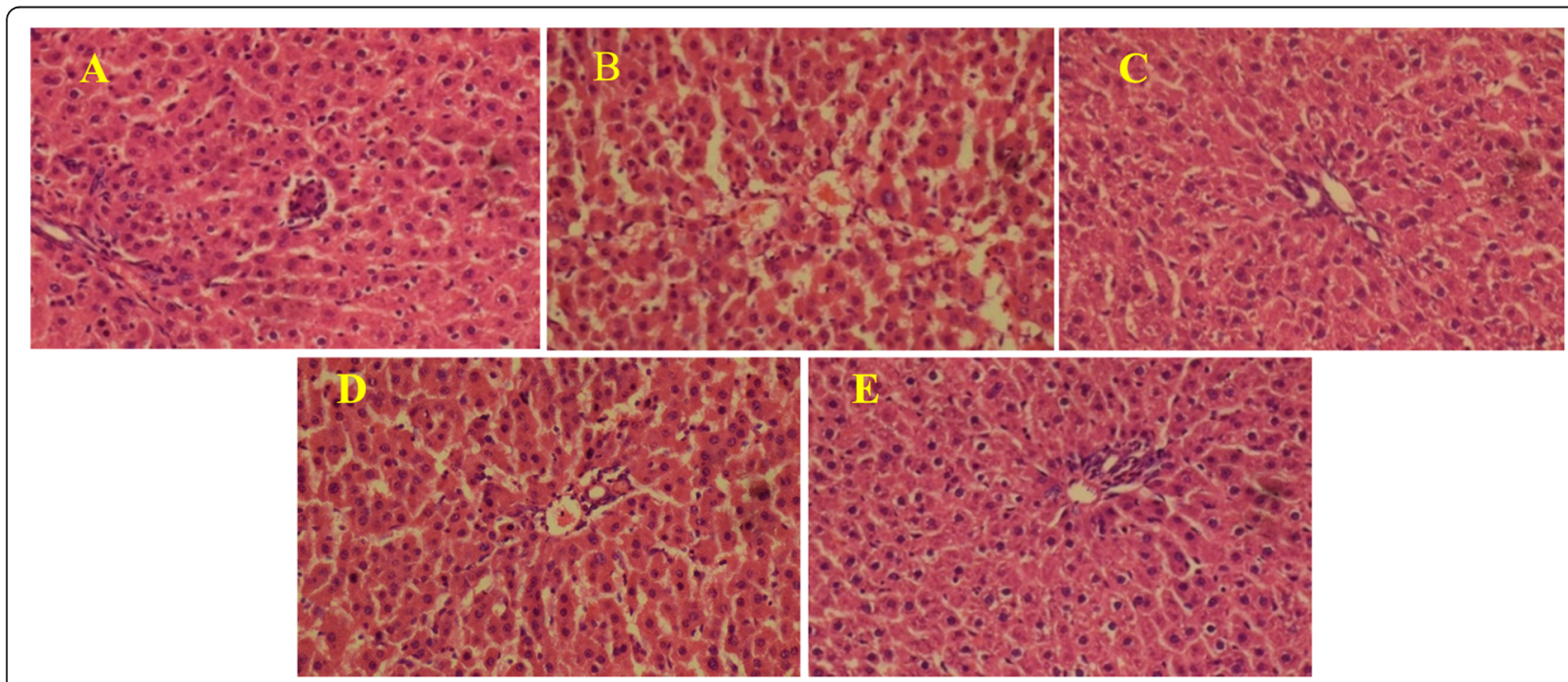

Fig. 4 Histological picture of liver architecture in $\mathrm{CCl}_{4}$ induced hepatotoxicity in rat. a (Liver architecture of Normal control), b (Liver architecture of $\mathrm{CCl}_{4}$ treated), $\mathbf{c}$ (Liver architecture $\mathrm{CCl}_{4}$ treatment $+50 \mathrm{mg} / \mathrm{kg}$ Silymarin treatment)), $\mathbf{d}$ (Liver architecture $\mathrm{CCl}_{4}$ treatment+ $200 \mathrm{mg} / \mathrm{kg}$ of GFME), e (Liver architecture $\mathrm{CCl}_{4}$ treatment+ $400 \mathrm{mg} / \mathrm{kg}$ of GFME) 
Table 3 Physicochemical properties

\begin{tabular}{|c|c|c|c|c|c|c|c|c|}
\hline \multirow{2}{*}{$\begin{array}{l}\text { Compound } \\
\text { name }\end{array}$} & \multirow{2}{*}{$\begin{array}{l}\text { Compound } \\
\text { (Chemspider } \\
\text { ID) }\end{array}$} & \multicolumn{7}{|c|}{ Physicochemical properties } \\
\hline & & $\mathrm{MW}$ & miLogP & TPSA & $\mathrm{nON}$ & $\mathrm{nOHNH}$ & nrotb & Volume \\
\hline Sylimarine & & 482.44 & 1.47 & 155.15 & 10 & 5 & 4 & 400.86 \\
\hline I & 106,997 & 144.12 & -0.46 & 66.76 & 4 & 2 & 0 & 123.40 \\
\hline$\|$ & $26,000,801$ & 126.11 & 0.56 & 50.44 & 3 & 1 & 2 & 109.42 \\
\hline III & $10,246,715$ & 192.17 & -2.33 & 118.21 & 6 & 5 & 1 & 161.46 \\
\hline
\end{tabular}

2,3-Dihydro-3,5-dihydroxy-6-methyl-4 h-pyran-4-one (Compound I), 2-furancarboxaldehyde 5-(hydroxymethyl)-(Compound II), and Quinic acid (Compound III)

Docking of compound I (2,3-Dihydro-3,5-dihydroxy-6-methyl-4 h-pyran-4-one), compound II (2-furancarboxaldehyde 5-(hydroxymethyl)-) and compound III (Quinic acid) ligand with PPAR $\alpha$ protein also showed a good level of inhibition with the binding affinity of $-5.5,-5.1$ and -6.2 respectively. There are comparatively good hydrogen bonding and good hydrophobic interactions against the amino acid molecules in relation to the PPAR $\alpha$ protein (Fig. 6) (Tables 5 and 6).

\section{Discussion}

The intensity of liver damage, ranging from subclinical icteric hepatitis to necro inflammatory hepatitis, cirrhosis and carcinoma have been proved to be associated with redox imbalance and oxidative stress [38]. A balance between oxidant and antioxidant intracellular systems is hence vital for cell function, regulation, and adaptation to diverse growth conditions. Excessive production of ROS may, however lead to oxidative stress, loss of cell function and ultimately apoptosis or necrosis. Recent research in the field of free radical biology suggested an important pathophysiological role of free radicals and oxidative stress in the development and progression of liver diseases [39]. Hence, antioxidants are frequently used to treat oxidative liver injury and the consumption of antioxidants is known to be an important means of preventing or delaying the appearance of liver diseases. The phytochemicals have effective antioxidant potential to treat various human diseases [40]. Antioxidant properties of bioactive compounds are responsible for the hepatoprotection by plant extracts. These compounds effectively reduce the oxidative stress and other inflammatory responses [41].
Plants are the potential source of bioactive compounds for the improvement of new therapeutical agents. The traditional medicine all over the world is at present revalued by an extensive activity of research on different plant species and their therapeutic principles. The utilization of plants as remedies existed thousands of years ago. The knowledge of utilizing specific plants for specific disorders was passed down via oral practice. Ultimately, herbal pharmacopeia records indication regarding medicinal plants [42]. Systematic surveys for medicinal plants have been commenced in many countries because of their contributions to health care. It was clear that the primary benefits of using plant-derived medicines are relatively safer than synthetic alternatives [43].

Natural products include herbals, extracts, formulations, etc., which have been used for the cure of many liver sicknesses in traditional systems of medicine. In the absence of reliable hepatoprotective drugs in modern medicine, a large number of medicinal plants with wellestablished traditional use have been recommended for the treatment of liver disorders [44]. In this study, the hepatoprotective effectiveness of Gardenia gummifera L.f. fruit extracts has been evaluated. This plant is known for its medicinal properties in indigenous medicine in India. It is very rich in phytocompounds, which gives a very strong purpose to select this plant for pharmacological assessment [45]. Earlier reports on medicinal plants suggest that alkaloids [46] and phenolic compounds [47] have wide potential biological properties. Numerous studies propose that the plant is having phenolic and alkaloids which has attracted an extreme deal of scientific and public interest due to the health-

Table 4 ADME and toxic properties

\begin{tabular}{|c|c|c|c|c|c|c|c|c|c|}
\hline \multicolumn{8}{|l|}{ ADME } & \multirow{2}{*}{\multicolumn{2}{|c|}{$\frac{\text { Toxicity }}{\text { Rodent Carcinogenicity }}$}} \\
\hline \multirow{2}{*}{$\begin{array}{l}\text { Compound } \\
\text { name }\end{array}$} & \multirow{2}{*}{$\begin{array}{l}\text { Chemspider } \\
\text { ID }\end{array}$} & \multirow{2}{*}{$\begin{array}{l}\text { HIA } \\
(\%)\end{array}$} & \multirow{2}{*}{$\begin{array}{l}\text { PPB } \\
(\%)\end{array}$} & \multirow{2}{*}{$\begin{array}{l}\text { BBB } \\
(\%)\end{array}$} & \multirow{2}{*}{$\begin{array}{l}\text { Cacok2 } \\
(\mathrm{nm} / \\
\mathrm{sec})\end{array}$} & \multirow{2}{*}{$\begin{array}{l}\text { Skin } \\
\text { Permeability }\end{array}$} & \multirow{2}{*}{$\begin{array}{l}\text { MDCK } \\
(\mathrm{nm} / \\
\mathrm{sec})\end{array}$} & & \\
\hline & & & & & & & & Carcino Mouse & Carcino Rat \\
\hline Silymarine & & 78.55 & 87.70 & 0.0596 & 7.852 & -4.236 & 0.0691 & negative & negative \\
\hline I & 106,997 & 75.91 & 38.437 & 0.273 & 1.85622 & -4.75733 & 24.0956 & negative & negative \\
\hline$\|$ & $26,000,801$ & 89.88 & 2.783 & 0.511 & 7.647 & -2.61671 & 158.521 & negative & positive \\
\hline$\|$ & $10,246,715$ & 20.28 & 6.595 & 0.428 & 8.27242 & -4.96717 & 0.530 & negative & positive \\
\hline
\end{tabular}

2,3-Dihydro-3,5-dihydroxy-6-methyl-4 h-pyran-4-one (Compound I), 2-furancarboxaldehyde 5-(hydroxymethyl)-(Compound II), and Quinic acid (Compound III). HIA: human intestinal absorption, PPB: plasma protein binding, BBB: the blood-brain barrier 


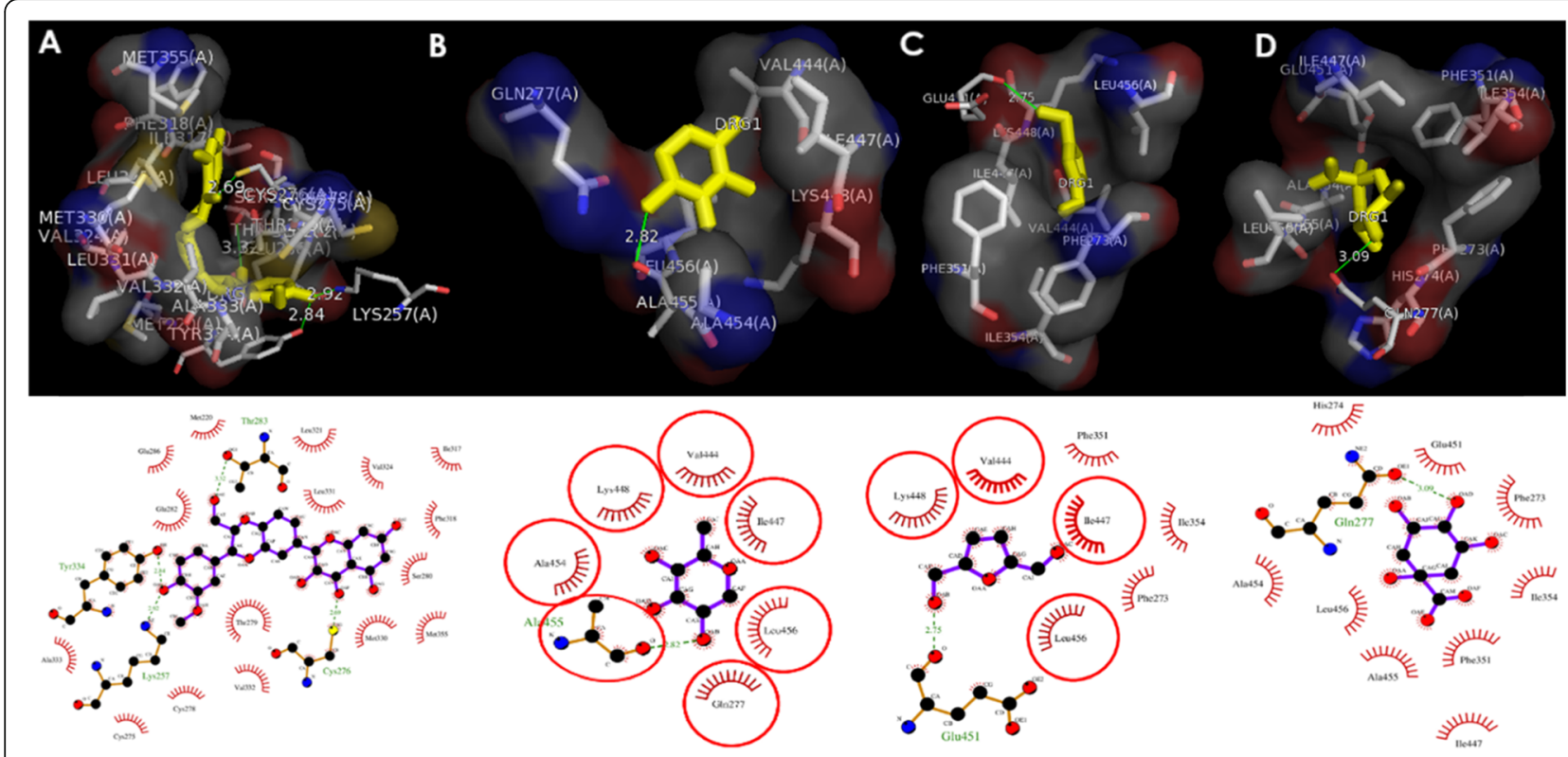

Fig. 5 Ligplot analysis and docking in relation to TGF- $\beta 1$. a Crystal structure of TGF- $\beta 1$, ligand Silymarin (Standard drug), b, c, d Crystal structures of TGF- $\beta 1$ with the ligands 2, 3-Dihydro-3, 5-dihydroxy-6-methyl-4 h-pyran-4-one, 2-furancarboxaldehyde 5-(hydroxymethyl)- and Quinic acid

promoting effects exhibited through a large array of biological activities as well as antioxidant properties [48]. $\mathrm{CCl}_{4}$ metabolism initiates with the trichloromethyl free radical by the action of the cytochrome P-450 oxygenase system. These free radicals, which are primarily formed as relatively unreactive, reacts very rapidly with oxygen to produce a highly reactive peroxytrichloromethyl $\left(\mathrm{CCl}_{3} \mathrm{OO}^{-}\right)$[49]. Both these derivatives are capable of covalently binding to proteins or lipids or abstracting a hydrogen atom from an unsaturated lipid, thus initiating lipid peroxidation of the cell membrane [50]. Thus, causing damage to cell membranes through disturbing $\mathrm{Ca} 2+$ homeostasis, varying enzyme activities, and lastly inducing hepatic damage. This lipid peroxidative degradation of the liver cell plasma membrane results in the release of a variety of enzymes such as SGPT, SGOT, and ALP. These are generally positioned in the cytosol and enters into the bloodstream. Estimating the

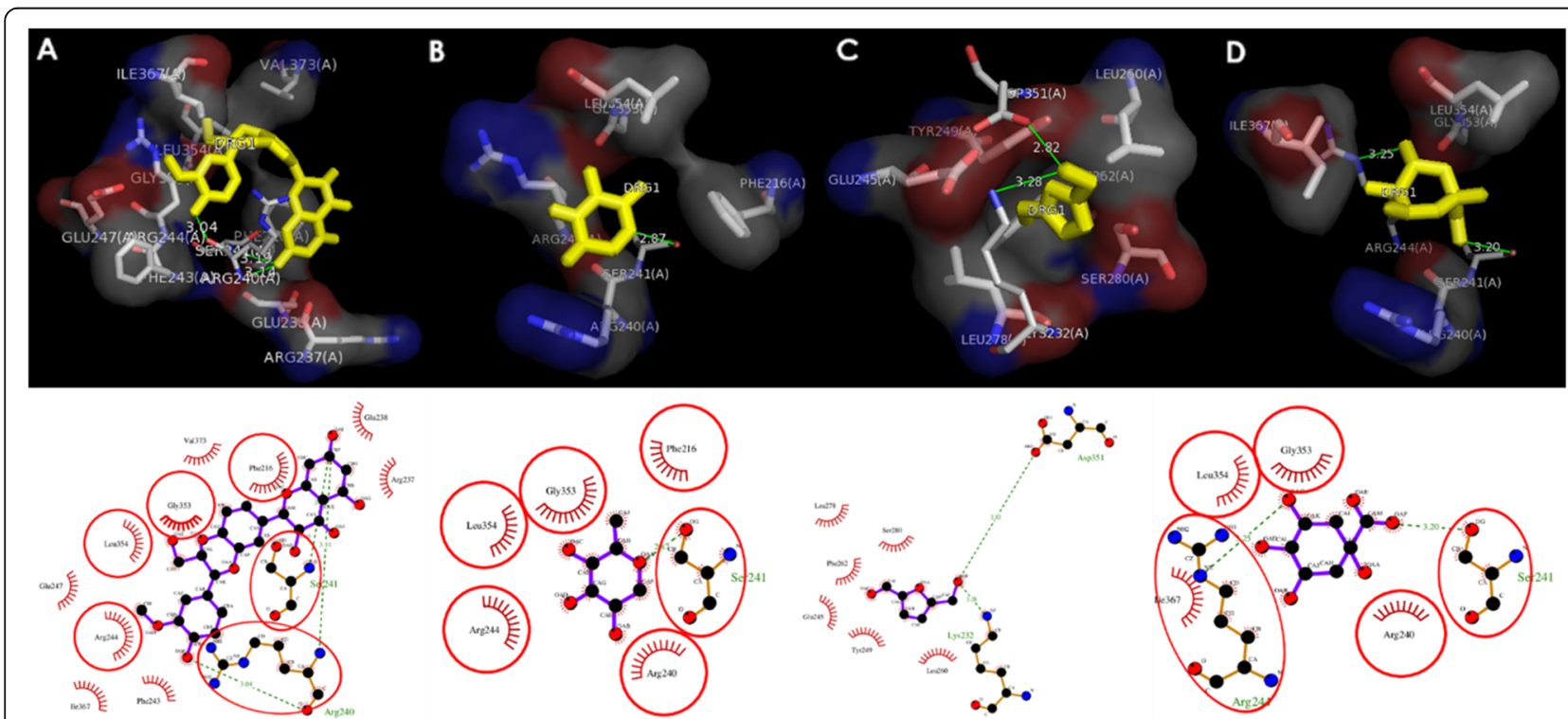

Fig. 6 Ligplot analysis and docking in relation to PPARa. a crystal structure of PPARa, ligand Silymarin (Standard drug), b, c, d Crystal structures of PPARa with the ligands 2,3-Dihydro-3,5-dihydroxy-6-methyl-4 h-pyran-4-one, 2-furancarboxaldehyde 5-(hydroxymethyl)- and Quinic acid 
Table 5 Binding energy, No. of $\mathrm{H}$ - Bonds, $\mathrm{H}$ - Bond length, $\mathrm{H}$-bond with and hydrophobic interactions of TGF- $\beta 1$ ligands with receptors

\begin{tabular}{lllllll}
\hline Ligands & $\begin{array}{l}\text { Target } \\
\text { Protein }\end{array}$ & $\begin{array}{l}\text { Affinity (kcal/ } \\
\text { mol) }\end{array}$ & $\begin{array}{l}\text { No. of H- } \\
\text { bonds }\end{array}$ & $\begin{array}{l}\text { H-bond } \\
\text { length (A) }\end{array}$ & $\begin{array}{l}\text { H-bond } \\
\text { with }\end{array}$ & Hydrophobic interactions \\
\hline Silymarin & TGF- $\beta 1$ & -6.8 & 3 & $\begin{array}{l}3.14,3.00 \\
3.04\end{array}$ & $\begin{array}{l}\text { Ser241 } \\
\text { Arg240 }\end{array}$ & $\begin{array}{l}\text { Phe243, Ile367, Arg244, Glu247, Leu354, Gly353, Val373, } \\
\text { Phe216, Glu238, Arg237 }\end{array}$ \\
$\begin{array}{llll}\text { Compound } \\
\text { I }\end{array}$ & -4.0 & 1 & 2.87 & Ser241 & Arg244, Leu354, Gly353, Phe216, Arg240 \\
Compound & -4.6 & 2 & 2.82 & Asp351 & Leu260, Tyr249, Glu245, Phe262, Leu278, Ser280 \\
II & & & 3.28 & Lys232 & \\
Compound & -4.3 & 2 & 3.20 & Ser241 & Leu354, Gly353, Arg240, Ile367 \\
III & & & 3.25 & Arg244 & \\
\hline
\end{tabular}

2,3-Dihydro-3,5-dihydroxy-6-methyl-4 h-pyran-4-one (Compound I), 2-furancarboxaldehyde 5-(hydroxymethyl)-(Compound II), and Quinic acid (Compound III)

actions of these serum marker enzymes facilitates the assessment of liver function [51]. In this study, the fruit methanol extract of Gardenia gummifera L.f. has been used.

The GFME showed the presence of a richness of phytochemicals. The phytochemical screening exposed that the GFME is rich in phytoconstituents such as alkaloids, phenolic compounds, terpenoids, and saponins. Similarly, the quantitative analysis showed the presence of phenolic and alkaloid compounds at the concentrations of $76.5 \mu \mathrm{g} / 1 \mathrm{mg}$ and $69.1 \mu \mathrm{g} / 1 \mathrm{mg}$ respectively. GC-MS results of GFME revealed the presence of 36 compounds. Among them, 2-Furancarboxaldehyde 5-(hydroxymethyl $)-\left(\mathrm{C}_{6} \mathrm{H}_{6} \mathrm{O}_{3}\right)$ showed the highest area of percentage (25.94), possessing anti-oxidant and proliferative activities. These compounds are potentially used for the cancer chemoprevention, inhibits the formation of sickled cells in the blood and also possesses antibacterial activity [52]. Another compound Quinic acid $\left(\mathrm{C}_{7} \mathrm{H}_{12} \mathrm{O}_{6}\right)$ showed an area of percentage 13.60 , which has been found to possesses potential antibacterial activity [53], used against colon cancer [54]. It has potent antioxidant [55] and anti-inflammatory activities [56].

GFME was evaluated for the DPPH and Nitric oxide radical scavenging assay with ascorbic acid as a standard compound (Table 2). The results revealed that as the concentration of the extract increases the activity also increases, Thus, indicates that the GFME possesses DPPH and Nitric oxide radical scavenging activities with the $\mathrm{IC}_{50}$ value of 131.11 and $175.95 \mu \mathrm{g} / \mathrm{ml}$ respectively. It is opined that the fruit extract possesses potent proton donating capacity and could serve as a free radical scavenger or inhibitor.

Antioxidants from natural products detoxify the toxins, removes excessive ROS, actively involves in antilipid peroxidation and scavenging of free radicals. In the present study, pre-treatment with GFME $(200 \mathrm{mg} / \mathrm{kg}$ and $400 \mathrm{mg} / \mathrm{kg}$ b.w) showed significantly reduced levels of SGPT, SGOT, ALP, TB and DB whereas the total protein levels increased significantly in the extract-treated group. The decrease in the levels of SGOT and SGPT indicates that the extract protected the structural integrity of the hepatocyte cell membrane by stimulating the restoration process of damaged cells. The significant increase in the total protein levels is an indication of the stabilization of endoplasmic reticulum leading to protein synthesis. Reduction in ALP, TB and DB levels reveals that the extract restored the stability of the biliary function during injury with $\mathrm{CCl}_{4}$. Thus, the results indicate that the GFME possesses protective activity against $\mathrm{CCl}_{4}$ induced toxicity.

The histological investigation of the liver sections revealed that the normal liver architecture was disturbed by hepatotoxin intoxication in the $\mathrm{CCl}_{4}$ treated group

Table 6 Binding energy, No. of H-Bonds, H- Bond length, H-bond with and hydrophobic interactions of PPARa ligands with receptors

\begin{tabular}{|c|c|c|c|c|c|c|}
\hline Ligands & $\begin{array}{l}\text { Target } \\
\text { Protein }\end{array}$ & $\begin{array}{l}\text { Affinity } \\
(\mathrm{kcal} / \mathrm{mol})\end{array}$ & $\begin{array}{l}\text { No. of } \mathrm{H}- \\
\text { bonds }\end{array}$ & $\begin{array}{l}\text { H-bond } \\
\text { length }(\AA)\end{array}$ & $\begin{array}{l}\text { H-bond } \\
\text { with }\end{array}$ & Hydrophobic interactions \\
\hline Silymarin & PPARa & -7.6 & 4 & $2.69,2.84$ & $\begin{array}{l}\text { Cys276 } \\
\text { Thr283 } \\
\text { Tyr334 }\end{array}$ & $\begin{array}{l}\text { Glu282, Glu286, Met220, Leu321, Leu331, Val324, Ile317, Phe318, Ser280, } \\
\text { Met355, Met330, Thr279, Val332, Cys278, Cys275, Ala333 }\end{array}$ \\
\hline Compound & & -5.5 & 1 & 2.82 & Ala455 & Ala454, Lys448, val444, Ile447, Leu456, Glu277 \\
\hline Compound & & -5.1 & 1 & 2.75 & Glu451 & Lys448, Val444, Phe351, Ile447, Ile354, Phe273, Leu456 \\
\hline Compound & & -6.2 & 1 & 3.09 & $G \ln 277$ & His274, Glu451, Phe273, Ile354, Phe351, Ala455, Leu456, Ala454 \\
\hline
\end{tabular}




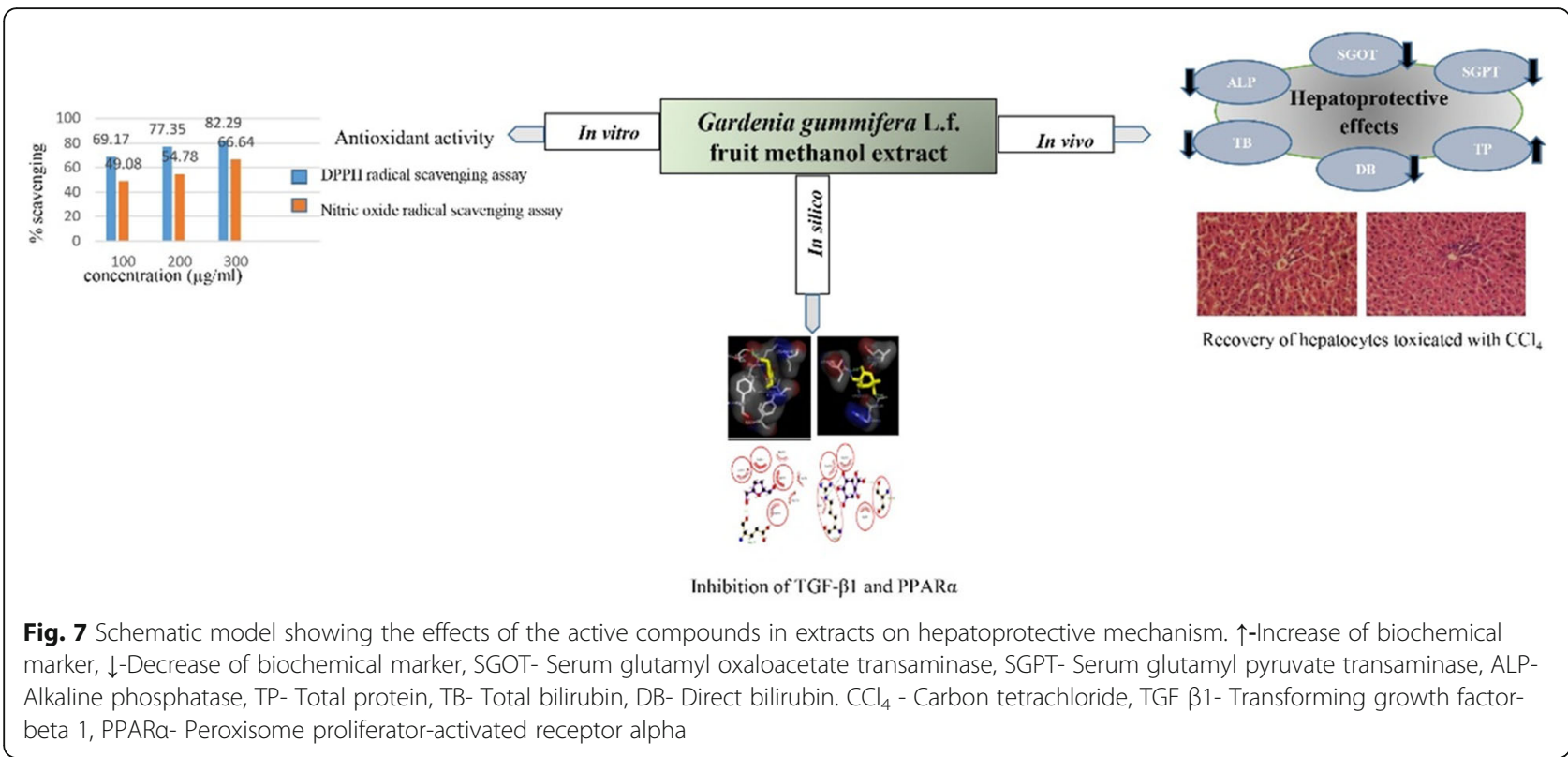

compared to the normal group (groups A and B) (Fig. 4). The combination of GFME $+\mathrm{CCl}_{4}(200 \mathrm{mg} / \mathrm{kg}$ and 400 $\mathrm{mg} / \mathrm{kg}$ ), (group D and E) exposure showed the recovery of damaged cells by retaining the usual arrangement of the central vein, radiating pattern of cell plates and nonappearance of fat droplets when compared to the hepatocytes of $\mathrm{CCl}_{4}$ damaged groups and further regeneration of hepatic cells was seen in the group $\mathrm{C}$ animals (Silymarin $+\mathrm{CCl}_{4}$ ). The histological observations provide supplementary support to the efficiency of the Gardenia fruit methanol extract in reducing liver damage caused by $\mathrm{CCl}_{4}$ intoxication.

The phytocompounds identified from GC-MS profiling obtained in higher concentrations were subjected to in silico analysis. A total of 36 phytocompounds were identified in the GC-MS analysis. Out of the total 03 were subjected for in silico analysis based on the area of percentage and their efficacy in terms of their antioxidant and pharmacological properties as established from the earlier reports [57-59].

In the process of drug development preliminary in silico analysis play a key role. The GC-MS analysis and screening of in vitro and in vivo efficacy of Gardenia gummifera L.f. have strengthened the traditional medicinal claim. Further studies were carried out to screen the ADMET properties and molecular docking. The targets were chosen based on the specificity of the literature data on the hepatoprotective mechanism [60]. The proteins, transforming growth factor-beta 1 (TGF- $\beta 1$ ) play a major role in redox imbalance by up-regulation of ROS production and the down regulation of the anti-oxidant defense system. Similarly, peroxisome proliferator-activated receptor $\alpha($ PPAR $\alpha)$, is a ligand-activated transcription factor and member of the superfamily of the nuclear hormone receptor, which plays a prominent role in maintaining glucose and lipid homeostasis by modulating gene expression of hepatocytes [61]. The in silico study predicted that the compounds I, II and III have not strictly violated any rule. Comparatively compound II has good bioactivity, good flexibility, and permeability and thus indicating its potentiality to be a good drug candidate. The above data may help for further analysis of pure compounds. Inhibition of proteins TGF- $\beta 1$ and PPAR $\alpha$ has been proposed as the most likely mechanism of the hepatoprotective effect. The effects of the active compounds in extracts on hepatoprotective mechanism depicted in Fig. 7. In general, it is predicted that among the phytocompounds tested the inhibition efficiency of compound II and compound III is nearly equal to a standard drug concerning target protein TGF- $\beta 1$ and PPAR $\alpha$ respectively. Hence, the in silico studies support the hepatoprotective activity Gardenia gummifera L.f. fruit methanol extract and the present prediction may help for the future screening of drug development on hepatic diseases.

\section{Conclusion}

The findings of this study showed that fruit methanolic extract of Gardenia gummifera L.f. exhibited potential protective action against the hepatotoxicity induced by $\mathrm{CCL}_{4}$. The hepatoprotective role of GFME might be due to the presence of chemical constituents like phenolic compounds and alkaloids. These phytocompounds may offer antioxidant activity and thus preventing the oxidative stress-induced in the liver. Hence, GFME may act as a prophylactic as well as a curative drug in treating hepatotoxic conditions. 


\section{Abbreviations}

GFME: Gardenia gummifera L.f. fruit methanol extract; ADME/T: Absorption distribution metabolism excretion toxicity; $\mathrm{CCl}_{4}$ : Carbon tetrachloride; PPARa: Peroxisome proliferator-activated receptor alpha; TGF-

$\beta 1$ : Transforming growth factor-beta 1; DPPH: 2,2-diphenylpicrylhydrazyl

\section{Acknowledgements}

The authors are thankful to DBT, New Delhi, India for providing financial support through DBT- BUILDER program (Order No. BT/PR9128/INF/22/190/ 2013, Dated: 30/06/2015) and the Kuvempu University administrative authority for offering the facility to carry out the work.

\section{Authors' contributions}

Concept - VNM; Design - VNM; RM; KV; Supervision - RM; KV; Resources VNM; RM; KV; Materials - VNM; RM; RB;KV;SLS; Data Collection and/or Processing - VNM; RB; SLS; Analysis and/or Interpretation - VNM; RM; KV; SLS Literature Search - VNM;RM; RB; SLS; Writing - VNM; RM; KV; Critical Reviews - VNM; RM; KV; RB; SLS; All authors read and approved the final manuscript.

\section{Funding}

The authors are thankful to DBT, New Delhi, India for providing financial support through DBT- BUILDER program.

\section{Availability of data and materials}

The datasets supporting the conclusions of this article are included within the article.

\section{Ethics approval}

The study protocol was approved by the National College of Pharmacy, Shimoga.

\section{Consent for publication}

Not applicable.

\section{Competing interests}

The authors declare that they have no competing interests.

Received: 4 December 2019 Accepted: 3 June 2020

Published online: 12 July 2020

\section{References}

1. Robinson MW, Harmon C, O'Farrelly C. Liver immunology and its role in inflammation and homeostasis. Cell Mol Immunol. 2016;13:267-76.

2. Zaefarian F, Abdollahi MR, Cowieson A, Ravindran V. Avian liver: the forgotten organ. Animals. 2019;9:1-23.

3. Pandit A, Sachdeva T, Bafna P. Drug-induced hepatotoxicity: a review. J App Pharm Sci. 2012;2:233-43.

4. Hurkadale PJ, Shelar PA, Palled SG, Mandavkar YD, Khedkar AS. Hepatoprotective activity of Amorphophallus paeoniifolius tubers against paracetamol-induced liver damage in rats. Asian Pac J Trop Biomed. 2012;2: 238-42

5. Kurutas EB. The importance of antioxidants which play the role in cellular response against oxidative/nitrosative stress: current state. Nutr J. 2016;15:1-22.

6. Guan YS, He Q. A current update on the rule of alternative and complementary medicine in the treatment of liver diseases. Evid Based Complement Altern Med. 2013;2013:1-10.

7. Xiong F, Guan YS. Cautiously using natural medicine to treat liver problems. World J Gastroenterol. 2017;23:3388-95.

8. Khurshid Alam AHM, Sharmin R, Maruf I, Hasibul Hasan J, Mohiuddin A, Golam M. Antidiabetic and hepatoprotective activities of Bombax ceiba young roots in alloxan-induced diabetic mice. J Nutr Health Food Sci. 2018; 6:1-7.

9. Ekor $M$. The growing use of herbal medicines: issues relating to adverse reactions and challenges in monitoring safety. Front Neurol. 2014;4:1-10.

10. Yuan $H, M a Q$, Ye L, Piao G. The traditional medicine and modern medicine from natural products. Molecules. 2016:21:1-18.

11. Veeresham C. Natural products derived from plants as a source of drugs. $J$ Adv Pharm Technol Res. 2012:3:200-1.

12. Chen IN, Chang CC, Ng CC, Wang CY, Shyu YT, Chang TL. Antioxidant and antimicrobial activity of Zingiberaceae plants in Taiwan. Plant Foods Human Nutr. 2008;63:15-20
13. Khare CP. Gardenia gummifera Linn. f. In: Indian medicinal plants; 2007. p. $1-1$.

14. Dolly PK. Innovative approach for assessing sustainability of the medicinal plant-Gardenia gummifera Linn. J Hortic For. 2014;6:14-21.

15. Nagar HK, Ranawat MS. Preliminary phytochemical screening, in vitro antioxidant activity, topical and oral formulation of extract of Woodfordia fructicosa and Gardenia gummifera. Int J Pharmacol Phytochem Ethnomed. 2017;8:16-26.

16. Kekuda PT, Raghavendra HL, Shilpa M, Pushpavathi D, Petkar T, Siddigha A. Antimicrobial, antiradical and insecticidal activity of Gardenia Gummifera L. F. (Rubiaceae). Int J Pharm Pharm Sci. 2017;9:265-72.

17. Reddy GC, Rangaswami S, Sunder R. Triterpenoids of the stem bark of Gardenia gummifera. Planta Med. 1977;32:206-11.

18. Lotfy RA, Fahmy D, Aly F. Qualitative and quantitative determination of secondary metabolites of 26 medicinal plants from southeastern of Egypt. Egypt J Desert Res. 2015;65:309-26.

19. Puneetha GK, Thriveni MC, Murali M, Shivamurthy GR, Niranjana SR, Prakash HS, Sadashiva MP, Amruthesh KN. Evaluation of a parasitic flowering plant Dendrophthoe trigona ( Wt. \& Arn.) Danser for its phytochemical and antioxidant activities. J Pharm Res. 2013;7:20-3.

20. Mujeeb F, Bajpai P, Pathak N. Phytochemical evaluation, antimicrobial activity, and determination of bioactive components from leaves of Aegle marmelos. Biomed Res Int. 2014;2014:1-11.

21. Gomathi D, Kalaiselvi M, Ravikumar G, Devaki K, Uma C. GC-MS analysis of bioactive compounds from the whole plant ethanolic extract of Evolvulus alsinoides (L.) L. J Food Sci Technol. 2013:52:1212-7.

22. Rajesh KP, Manjunatha $H$, Krishna V, Kumara Swamy BE. Potential in vitro antioxidant and protective effects of Mesua ferrea Linn. bark extracts on induced oxidative damage. Ind Crop Prod. 2013;47:186-98.

23. Kumaran A, Joel Karunakaran R. Antioxidant and free radical scavenging activity of an aqueous extract of Coleus aromaticus. Food Chem. 2006;97: 109-14.

24. Ghosh D, Mondal S, Ramakrishna K. Acute and sub-acute (30-day) toxicity studies of Aegialitis rotundifolia Roxb., leaves extract in Wistar rats: safety assessment of a rare mangrove traditionally utilized as pain antidote. Clin Phytosci. 2019:5:1-16.

25. Schlede E, Genschow E, Spielmann H, Stropp G, Kayser D. Oral acute toxic class method: A successful alternative to the oral LD50 test. Regul Toxicol Pharmacol. 2005:42:15-23.

26. Saleem U, Amin S, Ahmad B, Azeem H, Anwar F, Mary S. Acute oral toxicity evaluation of aqueous ethanolic extract of Saccharum munja Roxb. roots in albino mice as per OECD 425 TG. Toxicol Rep. 2017:4:580-5.

27. Bagban IM, Roy SP, Chaudhary A, Das SK, Gohil KJ, Bhandari KK. Hepatoprotective activity of the methanolic extract of Fagonia indica Burm in carbon tetra chloride induced hepatotoxicity in albino rats. Asian Pac J Trop Biomed. 2012;2:2-5

28. Senthilkumar R, Chandran R, Parimelazhagan T. Hepatoprotective effect of Rhodiola imbricata rhizome against paracetamol-induced liver toxicity in rats. Saudi J Biol Sci. 2014:21:409-16.

29. Kamisan FH, Yahya F, Ismail NA, Din SS, Mamat SS, Zabidi Z, et al. Hepatoprotective activity of methanol extract of Melastoma malabathricum leaf in rats. J Acupunct Meridian Stud. 2013;6:52-5.

30. Ojiako OA, Chikezie PC, Ogbuji AC. Histopathological studies of renal and hepatic tissues of hyperglycemic rats administered with traditional herbal formulations. Int J Green Pharm. 2015:9:184-91.

31. Guan L, Yang H, Cai Y, Sun L, Di P, Li W, et al. ADMET-score - a comprehensive scoring function for evaluation of chemical drug-likeness. Med Chem Commun. 2019;10:148-57.

32. Pence $\mathrm{EH}$, Williams $\mathrm{A}$. ChemSpider: an online chemical information resource J Chem Educ. 2010:87:1123-4.

33. Han Y, Zhang J, Hu CQ, Zhang X, Ma B, Zhang P. In silico ADME and toxicity prediction of ceftazidime and its impurities. Front Pharmacol. 2019:10:1-12.

34. Chandra, Puttaraju KB, Mahesh SS, Shivashankar K, Lokanath NK, Madegowda M. Molecular docking studies of benzimidazopyrimidine and coumarin substituted benzimidazopyrimidine derivatives: as potential human Aurora A kinase inhibitors. Bioinformation. 2014;10:288-92.

35. Sun B, Karin M. NF-kB signaling, liver disease and hepatoprotective agents. Oncogene. 2008:27:6228-44.

36. Jinadatta P, Rajshekarappa S, Sundera Raja Rao K, Pasura Subbaiah SG, Shastri S. In silico, in vitro: antioxidant and antihepatotoxic activity of gnetol from Gnetum ula Brongn. Bioimpacts. 2019;9:239-49. 
37. Meng XY, Zhang HX, Mezei M, Cui M. Molecular docking: a powerful approach for structure-based drug discovery. Current computer aided-drug design. Curr Comput Aided Drug Des. 2011;7:146-57.

38. Wu D, Cederbaum A. Oxidative stress and alcoholic liver disease. Semin Liver Dis. 2009;29:141-54

39. Nita M, Grzybowski A. The role of the reactive oxygen species and oxidative stress in the pathomechanism of the age-related ocular diseases and other pathologies of the anterior and posterior eye segments in adults. Oxidative Med Cell Longev. 2016;2016:1-23.

40. Zhang Y-J, Gan R-Y, Li S, Zhou Y, Li A-N, Xu D-P, et al. Antioxidant phytochemicals for the prevention and treatment of chronic diseases. Molecules. 2015;20:21138-56.

41. Jeyadevi R, Ananth DA, Sivasudha T. Hepatoprotective and antioxidant activity of Ipomoea staphylina Linn. Clin Phytosci. 2019;5:1-11.

42. Atanasov AG, Waltenberger B, Pferschy-Wenzig E-M, Linder T, Wawrosch C, Uhrin $P$, et al. Discovery and resupply of pharmacologically active plantderived natural products: a review. Biotechnol Adv. 2015:33:1582-14.

43. Dias DA, Urban S, Roessner U. A historical overview of natural products in drug discovery. Metabolites. 2012;2:303-36.

44. Sachin C, Ajay P. Indian medicinal plants used in liver disease: a short review. Pharmacogn J. 2011:3:91-4.

45. Gandhe S, Lakavath S, Palatheeya S, Schuehly W, Amancha K, Kiran Reddy Nallamaddi R, et al. Cycloartanes from the gum resin of Gardenia gummifera L.f. Chem Biodivers. 2013;10:1613-22.

46. Hussain G, Rasul A, Anwar H, Aziz N, Razzaq A, Wei W, et al. Role of plant derived alkaloids and their mechanism in neurodegenerative disorders. Int J Biol Sci. 2018;14:341-57.

47. Lin D, Xiao M, Zhao J, Li Z, Xing B, Li X, et al. An overview of plant phenolic compounds and their importance in human nutrition and management of type 2 diabetes. Molecules. 2016;21:1-19.

48. Lemus-Mondaca R, Vega-Gálvez A, Rojas P, Stucken K, Delporte C, Valenzuela-Barra G, et al. Antioxidant, antimicrobial and anti-inflammatory potential of Stevia rebaudiana leaves: effect of different drying methods. J Appl Res Med Aromat Plants. 2018;11:37-46.

49. Soni B, Visavadiya NP, Madamwar D. Ameliorative action of cyanobacterial phycoerythrin on $\mathrm{CCl}_{4}$-induced toxicity in rats. Toxicology. 2008;248:59-65.

50. Mahmoodzadeh Y, Mazani M, Rezagholizadeh L. Hepatoprotective effect of methanolic Tanacetum parthenium extract on $\mathrm{CCl}_{4}$-induced liver damage in rats. Toxicol Rep. 2017:4:455-62.

51. Mahmud ZA, Bachar SC, Qais N. Antioxidant and hepatoprotective activities of ethanolic extracts of leaves of Premna esculenta Roxb. against carbon tetrachloride-induced liver damage in rats. J Young Pharm. 2012;4:228-34

52. Zhao L, Chen J, Su J, Li L, Hu S, Li B, et al. In vitro antioxidant and antiproliferative activities of 5-hydroxymethylfurfural. J Agric Food Chem. 2013:61:10604-11.

53. Rezende CO, Oliveira LA, Oliveira BA, Almeida CG, Ferreira BS, Le Hyaric M, et al. Synthesis and antibacterial activity of alkylated diamines and amphiphilic amides of quinic acid derivatives. Chem Biol Drug Des. 2015;86: 344-50.

54. Liu ZH, Zhang SY, Yu YY, Su GQ. (-)-4-O-(4-O- $\beta$-D-glucopyranosylcaffeoyl) quinic acid presents antitumor activity in HT-29 human colon cancer in vitro and in vivo. Mol Cell Toxicol. 2015;11:457-63.

55. Soh Y, Kim JA, Sohn NW, Kang RL, Sun YK. Protective effects of quinic acid derivatives on tetrahydropapaveroline- induced cell death in C6 glioma cells. Biol Pharm Bull. 2003:26:803-7.

56. Zeng K, Thompson KE, Yates CR, Miller DD. Synthesis and biological evaluation of quinic acid derivatives as anti-inflammatory agents. Bioorg Med Chem Lett. 2009;19:5458-60

57. Uranga JG, Podio NS, Wunderlin DA, Santiago AN. Theoretical and experimental study of the antioxidant behaviors of 5-O-Caffeoylquinic, quinic and caffeic acids based on electronic and structural properties. ChemistrySelect. 2016;1:4113-20.

58. Lin A-S, Qian K, Usami Y, Lin L, Itokawa H, Hsu C, et al. 5-Hydroxymethyl-2furfural, a clinical trials agent for sickle cell anemia, and its mono/diglucosides from classically processed steamed Rehmanniae Radix. J Nat Med. 2007:62:164-7.

59. Čechovská L, Cejpek K, Konečný M, Velíšek J. On the role of 2,3-dihydro-3,5dihydroxy-6-methyl-(4H)-pyran-4-one in antioxidant capacity of prunes. Eur Food Res Technol. 2011;233:367-76.

60. Malek S, Huang DB, Huxford T, Ghosh S, Ghosh G. X-ray crystal structure of an IkBB.NF-kB p65 homodimer complex. J Biol Chem. 2003;278:23094-100.
61. Rigano D, Sirignano C, Taglialatela-Scafati O. The potential of natural products for targeting PPAR a. Acta Pharm Sin B. 2017;7:427-38.

\section{Publisher's Note}

Springer Nature remains neutral with regard to jurisdictional claims in published maps and institutional affiliations.

\section{Submit your manuscript to a SpringerOpen ${ }^{\circ}$ journal and benefit from:}

- Convenient online submission

- Rigorous peer review

- Open access: articles freely available online

- High visibility within the field

- Retaining the copyright to your article

Submit your next manuscript at $>$ springeropen.com 